\title{
KELELAHAN KERJA BERHUBUNGAN DENGAN KINERJAPERAWAT DI RUANG ISOLASI COVID 19
}

Tria Adeningsih Purba*, Nurhayati Siagian

Fakultas Ilmu Keperawatan, Universitas Advent Indonesia, Jl. Kolonel Masturi No.288, Cihanjuang Rahayu, Kec. Parongpong, Kabupaten Bandung Barat, Jawa Barat 40559, Indonesia

*triapurba30@gmail.com (+6282160440166)

\begin{abstract}
ABSTRAK
Perawat memiliki peran yang penting dalam pelayanan kesehatan di rumah sakit. Kelelahan kerja sangat mempengaruhi perawat karena berpengaruh pada kinerja kerja. Dengan mengetahui hubungan kelelahan dan kinerja perawat dapat lebih meningkatkan kualitas pelayanan yang lebih baik. Tujuan penelitian Untuk mengetahui hubungan antara kelelahan kerja dengan kinerja perawat di ruang Isolasi Covid 19 Rumah Sakit Bandar Lampung. Metode penelitian ialah deskriptif analitik dengan pendekatan cross sectional dan pengambilan sampel menggunakan teknik purposive sampling. Responden dalam penelitian ini ialah seluruh perawat ruang Isolasi Covid 19 di Rumah Sakit Advent Bandar Lampung yang berjumlah 61 perawat. Pengumpulan data menggunakan kuesioner kelelahan kerja (nilai cronbach alpha $=0,920>r=0,333$ ) dan kinerja perawat (cronbach alpha $=0,951$ ) di analisa dengan pearson correlation. Hasil uji analisa statistic didapati nilai $p=-, 148<0,05$ berarti ada hubungan yang signifikan antara kelelahan kerja dengan kinerja perawat.
\end{abstract}

Kata kunci: kelelahan kerja; kinerja perawat; perawat

\section{WORK FATIGUE RELATES TO THE PERFORMANCE OF THE NURSE IN THE ROOM ISOLATION COVID 19}

\begin{abstract}
Nurses have an important role in health care in the hospital. Work fatigue greatly affects nurses because it affects work performance. By knowing the relationship between fatigue and nurse performance can further improve service quality better. The research objective was to determine the relationship between work fatigue and the performance of nurses in the Covid 19 isolation room in Bandar Lampung Hospital. The research method is descriptive analytic with cross sectional approach and sampling using purposive sampling technique. Respondents in this study were al nurses in the Covid 19 isolation room at the Bandar Lampung Adventist Hospital totaling 61 nurses. The data were collected using a work fatigue questionnaire (cronbach alpha value $=0,920>r=0,333$ ) and nurses' performance (cronbach alpha $=0,951$ ) was analyzed using the Pearson correlation. The results of statistical analysis showed that the value of $p=1,148<0,05$ means that there is a significant relationship between work fatigue and the performance of nurses.
\end{abstract}

Keywords: nurse; nurse performance; work fatigue

\section{PENDAHULUAN}

Perawat adalah salah satu sumber daya manusia yang berperan penting di dalam pelayanan kesehatan yang ada di rumah sakit (Gurning, Luthfi, \& Pratama, 2020). Marthalena, Nuruddin, dan Surmiarsih (2020) menambahkan perawat merupakan kekayaan utama dalam suatu rumah sakit, dikarenakan tanpa peranan perawat, aktivitas di rumah sakit tidak terjadi.

Tantangan, beban kerja yang tinggi, 
kelelahan, stresor internal dan eksternal sering terjadi pada tenaga kesehatan. Masalah stres kerja merupakan masalah yang perlu mendapat perhatian karena akan berdampak pada produktivitas dan kinerja (Handini, Kusnanto, \& Yuswanto, 2020). Kinerja atau performance merupakan fungsi dari kemampuan (ability), motivasi (motivation) dan kesempatan (opportunity). Perawat dengan kinerja yang baik merupakan hal terpenting dalam peningkatan kualitas pelayanan. Disisi lain sering ditemukan keluhan yang berkaitan dengan kualitas pelayanan kesehatan yang berasal dari perawat (Bidjuni, Kalalo, \& Majore, 2018).

Menurunnya kinerja sama artinya dengan menurunnya produktivitas kerja. Apabila tingkat produktivitas seorang tenaga kerja terganggu yang disebabkan oleh faktor kelelahan fisik maupun psikis maka akibat yang ditimbulkannya akan dirasakan oleh perusahaan berupa penurunan produktivitas perusahaan (Lutfhi, Pratama, Gurning, 2020). Salah satu faktor yang dapat mempengaruhi kinerja ialah kelelahan, kelelahan kerja bisa menyebabkan penurunan kinerja yang dapat berakibat kepada kesalahan kerja ataupun kecelakaan kerja (Hidayat, 2016).

Kelelahan (fatigue) merupakan suatu keluhan yang paling umum terjadi pada masyarakat dan pada populasi pekerja. Kelelahan kerja bisa terjadi pada saat pelaksanaan proses kerja. Kelelahan kerja sangat mempengaruhi seseorang sehingga dapat menurunkan konsentrasi kinerja perawat, dan menurunnya konsentrasi kerja perawat. Apabila kelelahan tidak ditanggapi lebih lanjut dan pekerja tetap dipaksa untuk terus bekerja, kelelahan akan semakin memburuk dan akan berakibat pada penurunan kemampuan fisik dan mental serta kehilangan efisiensi kerja (Bidjuni, Kalalo, \& Majore, 2018).

Menurut World Health Organization (WHO) dalam model kesehatan yang dibuat sampai pada tahun 2020 diramalkan bahwa gangguan psikis berupa perasaan Lelah yang berat dan berujung pada depresi akan menjadi penyakit pembunuh noro dua setelah penyakit jantung (Munandar, Permatasari, \& Rezal, 2017). Muller (2020) melaporkan bahwa menurut laporan survei 2018 oleh National Safety Concil (NSC), dua pertiga angkatan kerja AS mengalami kelelahan di tempat kerja yang berarti, hampir 107 juta dari 160 juta pekerja AS terkena kelelahan kerja. Menurut World Health Organization (WHO) dalam model kesehatan yang dibuat sampai pada tahun 2020 diramalkan bahwa gangguan psikis berupa perasaan Lelah yang berat dan berujung pada depresi akan menjadi penyakit pembunuh noro dua setelah penyakit jantung (Munandar, Permatasari, \& Rezal, 2017). Muller (2020) melaporkan bahwa menurut laporan survei 2018 oleh National Safety Concil (NSC), dua pertiga angkatan kerja AS mengalami kelelahan di tempat kerja yang berarti, hampir 107 juta dari 160 juta pekerja AS terkena kelelahan kerja.

Data dari International Labour Organization (ILO) menunjukkan bahwa hampir setiap tahun sebanyak dua juta pekerja meninggal dunia karena kecelakaan kerja yang disebabkan oleh faktor kelelahan (Karbito \& Oksandi, 2020). Menurut Departemen Tenaga Kerja (2016) di Indonesia pada tahun 2013 didapati bahwa data mengenai kecelakaan kerja setiap harinya rata-rata terjadi 414 
kecelakaan kerja, dan 27,8\% disebabkan kelelahan yang cukup tinggi. Bidjuni, Kalalo, dan Majore (2018).

Kelelahan kerja yang dialami tenaga kesehatan harus menjadi perhatian oleh pihak Rumah Sakit terkhususnya perawat yang memliki peran penting bagi rumah sakit. Kelelahan kerja akan menyebabkan menurunnya kinerja dan menambah kesalahan kerja (Lutfhi, Pratama, Gurning, 2020). Hasil penelitian yang telah dilakukan oleh Bidjuni, Kalalo, dan Majore pada tahun 2018 didapati bahwa terdapat hubungan antara kelelahan kerja dengan kinerja perawat di Instalasi Rawat Inap RSU Pancaran Kasih GMIM Manado dengan nilai $p=0,023<\alpha=0,05$.

Hasil observasi dan wawancara terhadap 3 sampai 5 perawat, peneliti mendapati bahwa adanya keluhan kelelahan kerja yang mengganggu kinerja perawat di ruangan perawatan dan menyebabkan adanya kualitas pelayanan yang kurang baik. Berdasarkan uraian diatas, maka peneliti bertujuan untuk mengetahui gambaran kelelahan perawat, gambaran kinerja perawat dan mencari tahu hubungan kelelahan kerja dengan kinerja perawat di Ruang Isolasi Covid19 di Rumah Sakit Advent Bandar Lampung".

\section{METODE}

Penelitian ini bersifat deskriptif analitik dengan pendekatan cross sectional dimana data yang menyangkut variable bebas atau risiko akan dikumpulkan dalam waktu yang bersama. Penelitian telah dilaksanakan di Ruang Isolasi Covid 19 Rumah Sakit Advent Bandar Lampung. Penelitian ini telah dilaksanakan pada tanggal 09 April 2021 sampai 12 April 2021. Populasi penelitian ini adalah seluruh tenaga perawat di ruang Isolasi Rumah Sakit Advent Bandar Lampung sebanyak 61 orang. Sampel dalam penelitian ini adalah total sampling diambil berdasarkan dengan teknik purposive sampling. Kriteria inklusi : Perawat yang bekerja di Ruang Isolasi Covid 19 Rumah Sakit Advent Bandar Lampung, perawat yang bersedia menjadi responden dengan mengisi surat kesediaan menjadi responden. Kriteria eksklusi tenaga kesehatan lainnya selain perawat.

Instrumen yang digunakan dalam penelitian ini ialah kuesioner kelelahan kerja yang diadopsi dari Amani (2019) dimana kuesioner dinyatakan valid bila hasil uji reliabilitas nilai cronbach alpha adalah sebesar 0,920 yang berarti lebih besar dari nilai $r$ table $=0,333$, sehingga instrument penelitain dinyatakan reliable. Jumlah pertanyaan sebanyak 30 butir, dinilai menggunakan skala Likert dimana 0: Tidak Pernah, 1: Kadang-Kadang, 2: Sering, dan 3: Sangat Sering. Sedangkan kuesioner kinerja perawat diadopsi dari penelitian Fardiana (2018) dengan hasil uji reliabilitas nilai cronbach alpha adalah sebesar 0,951 yang menunjukkan bahwa pertanyaan dalam kuesioner sangat reliable. Jumlah pertanyaan sebanyak 30 butir, dinilai menggunakan skala Likert, dimana 1: Tidak Pernah, 2: Jarang, 3: Kadang-kadang, 4: Sering, dan 5: Selalu. Analisa data dilakukan dengan mencari distribusi frekuensi dan dilakukan uji hubungan dengan pearson correlation.

\section{HASIL}

Hasil yang didapatkan dari tabel 1, diketahui bahwa dari 61 perawat didapati mayoritas berjenis kelamin perempuan $84 \%$ (51 perawat). Dengan batasan usia 26-30 yang terbanyak yaitu 
$38 \%$ (23 perawat). Tabel 2 didapati bahwa dari 61 responden mayoritas perawat berada pada tingkat tidak lelah yaitu sebanya $92 \%$ (56 perawat). Tabel 3 menunjukkan bahwa 100\% (61 perawat)memiliki kinerja yang baik.

Tabel 1.

Karakteristik Perawat di Ruang Isolasi Covid 19 (n=61)

\begin{tabular}{lcc}
\hline \multicolumn{1}{c}{ Karalteristik } & $\mathrm{f}$ & $\%$ \\
\hline Jenis Kelamin & & 16 \\
\hline Laki-laki & 10 & 84 \\
Perempuan & 51 & \\
\hline Usia & & 25 \\
\hline $21-25$ & 15 & 38 \\
$26-30$ & 23 & 18 \\
$31-35$ & 11 & 13 \\
$36-40$ & 8 & 6 \\
$41-45$ & 4 & \\
\hline
\end{tabular}

Tabel 2.

Tingkat Kelelahan Kerja Perawat di Ruang Isolasi ( $\mathrm{n}=61$ )

\begin{tabular}{lcc}
\hline Kelelahan Kerja & $\mathrm{f}$ & $\%$ \\
\hline Lelah & 5 & 8 \\
Tidak Lelah & 56 & 92 \\
\hline
\end{tabular}

Tabel 3.

Tingkat Kinerja Perawat di Ruang Isolasi ( $\mathrm{n}=61)$

\begin{tabular}{lcc}
\hline \multicolumn{1}{c}{ Kinerja } & $\mathrm{f}$ & $\%$ \\
\hline Baik & 61 & 100 \\
\hline Kurang Baik & 0 & 0 \\
\hline
\end{tabular}

Tabel 4.

Hubungan Kelelahan Kerja dengan Kinerja Perawat di Ruang Isolasi ( $\mathrm{n}=61)$

\begin{tabular}{llcc}
\hline & & Kinerja & Kelelahan \\
\hline Pearson & Kinerja & 1,000 & -0148 \\
\hline Correlation & Kelelahan & $-0,148$ & 1,000 \\
\hline Sig. (1-tailed) & Kinerja & 0,0 & 0,127 \\
\hline $\mathrm{N}$ & Kelelahan & 0,127 & 0,0 \\
\hline
\end{tabular}

Hasil yang didapati berdasarkan pada tabel 3 , nilai $p=-, 148<0,05$ artinya $\mathrm{H} 0$ ditolak dan $\mathrm{H} 1$ diterima yang berarti adanya hubungan yang signifikan antara kelelahan kerja dengan kinerja perawat. Nilai korelasi didapati hasil negatif dimana jika semakin tinggi tingkat kelelahan maka semakin rendah kinerja perawat, dan begitu pula sebaliknya.

\section{PEMBAHASAN}

Hasil deskriptif karakteristik perawat didapati bahwa mayoritas perawat berjenis kelamin perempuan $84 \%$ (51 perawat), dengan batasan usia terbanyak yaitu 26-30 tahun sebanyak $38 \%$ (23 perawat). Sejalan dengan penelitian yang dilakukan oleh Hernadewita, Iridiastadi, Septiawati, dan Yuliani (2020) di salah satu Rumah 
Sakit Militer di Indonesia didapati kebanyakan perawat berjenis kelamin wanita, yaitu $90,24 \%$ (37 perawat) dan batasan usia 26-30 adalah terbanyak yaitu $43,90 \%$ (18 perawat). Begitupula, hasil yang didapati oleh Bidjuni, Kallo, dan Pangemanan (2019) bahwa kebanyakan perawat di Rumah Sakit Bhayangkara Manado berjenis kelamin perempuan $81,08 \% \quad(30$ perawat $)$ berusia 26-30 tahun, yaitu 54,05\% (20 perawat).

Hasil deskriptif tingkat kelelahan kerja perawat menunjukkan mayoritas perawat berada pada tingkat tidak lelah yaitu sebanyak 92\% (56 perawat). Hasil penelitian ini sejalan dengan hasil yang didapatkan oleh Bidjuni, Kalalo, dan Majore (2018) dimana ditemukan bahwa kebanyak responden merasa tidak lelah, yaitu sebanyak 79\% (35 perawat). Berbanding terbalik dengan penelitian yang dilakukan oleh Herlina dan Kondi (2019) di Rumah Sakit Awal Bross Bekasi didapati perawat yang merasa lelah lebih banyak yaitu sebanyak 51\% (31 perawat).

Hasil wawancara dan pengisian kuesioner peneliti mendapati kelulahan kelelahan kerja perawat berada pada tingkat tidak lelah dikarenakan perawat di ruang isolasi merasa ada pembagian waktu yang diatur dengan baik dan pada saat bersamaan pasien tidak begitu banyak sehingga beban kerja perawat tidak berlebihan.

Salah satu penyebab terjadinya kelelahan kerja yaitu beban kerja fisik (Astuti, Ekawati, \& Wahyuni, 2017). Dilain sisi pembagian shift, pelimpahan tugas dan tanggung jawab yang sesuai dengan kemampuan, lingkungan kerja yang nyaman, aman , tenang, sarana dan prasarana yang baik, waktu kerja yang cukup mampu membantu mengurangi kelelahan untuk perawat (Noviyanti \& Supriyadi, 2020).

Hasil yang didapati berdasarkan tabel 3 menunjukkan bahwa seluruh perawat memiliki kinerja yang baik, yaitu $100 \%$ (61 perawat). Sejalan dengan penelitian yang dilakukan oleh Bidjuni, Kalalo, dan Majore (2018) ditemukan responden dengan kinerja yang baik sebanyak 90\% (40 perawat). Sama dengan penelitian yang dilakukan oleh Agni, Rebanti, dan Unatari (2017) didapati perawat dengan kinerja yang baik adalah paling banyak yaitu $84,1 \%$ (58 perawat).

Peneliti mendapati melalui hasil wawancara dan pengisian kuesioner mengenai kinerja perawat baik karena adanya motivasi yang baik dari atasan, untuk memenuhi tuntutan juga tanggung jawab sebagai perawat profesional dan merasa psikis, sosial maupun fisik dalam keadaan baik. Kesehatan fisik perawat sangatlah penting untuk diperhatikan dalam proses pelayanan perawatan, status kesehatan fisik perawat dapat mempengaruhi kinerja perawat dalam pemenuhan kebutuhan pasien (Didjo \& I, 2020).

Motivasi perawat yang baik merupakan kunci utama yang menentukan kinerja perawat karena dalam memberikan asuhan keperawatan perawat harus memiliki dorongan dan kemauan yang kuatuntuk melaksanakan sesuai dengan tahapan dan standar yang telah ditetapkan (Fitriani, L, Muhammad, \& Rezeki, 2020).

Berdasarkan tabel 4 , didapati hasil nilai $p=-, 148<0,05$ yang berarti H0 ditolak dan H1 diterima dimana terdapat hubungan yang signifikan antara kelelahan kerja dengan kinerja perawat. 
Sama dengan penelitian yang dilakukan oleh Bidjuni, Kalalo, dan Majore (2018) dimana didapatkan nilai $p=0,023<0,05$ yang artinya $\mathrm{H} 0$ ditolak dan $\mathrm{Ha}$ diterima atau terdapat hubungan yang signifikan antara kelelahan kerja dengan kinerja perawat. Kinerja perawat dapat menurun jika tidak segera ditangani, karena penurunan kinerja akan mempengaruhi mutu pelayanan kesehatan (Didjo \& I, 2020). Salah satu faktor yang dapat mempengaruhi kinerja ialah kelelahan, kelelahan kerja bisa menyebabkan penurunan kinerja yang dapat berakibat kepada kesalahan kerja ataupun kecelakaan kerja (Hidayat, 2016).

Faktor yang menyebabkan kelelahan yang juga merupakan pemicu kinerja yang lebih buruk antaralain ialah faktor lingkungan kerja, kenyamanan, iklim organisasi dan pendapatan. Upaya penanggulangan kelelahan ialah dengan menurunkan faktor penyebabnya, dengan demikian akan kesuksesan suatu organisasi menjadi nyata (Cahyandi, Hendrawan, Indriyani, \& Sucahyawati, 2018).

Kinerja perawat merupakan aspek penting dalam rumah sakit, karena hal inilah yang akan menentukan kemajuan suatu rumah sakit (Fitriani, L, Muhammad, \& Rezeki, 2020). Kinerja baik yang dimiliki oleh perawat pelaksana dan juga penerapan proses keperawatan yang benar sesuai standar akan menjamin kepuasan setiap pengunjung rumah sakit karena pelayanan keperawatan yang diberikan (Bidjuni, Kalalo, \& Majore, 2018).

\section{SIMPULAN}

Setelah dilakukan analisis terhadap 18 artikel yang diterbitkan tahun 2012 hingga 2020, pada masa work from home akademisi tidak hanya melakukan pekerjaannya saja melainkan melakukan pekerjaan rumah serta pekerjaan kantor yang biasanya bisa menghabiskan waktu hingga berjam jam untuk duduk dan menyelesaikan pekerjaan kantor dan juga mengajar dan dengan demikian dapat disimpulkan bahwa adanya potensi antara work from home dan gangguan work related musculoskeletal disorders di kalangan akademisi sangat relevan.

\section{DAFTAR PUSTAKA}

Agni, M., Rebanti, L., \& Unatari, J. (2017). Faktor-Faktor yang berhubungan dengan Tingkat Kinerja Perawat di Ruang Rawat Inap RSUD Panembahan Senopati Bantul. Jurnal Formil (Forum Ilmiah) KesMas Respati, Volume 2, Nomor 2, 29-37.

Astuti, F., Ekawati, \& Wahyuni, I. (2017). Hubungan antara Faktor Individu, Beban Kerja dan Shift Kerja dengan Kelelahan Kerja pada Perawat di RSJD Dr. Amino Gondohutomo Semaran. Jurnal Kesehatan Masyarakat (eJournal), Volume 5, Nomor 5, 163-172.

Bidjuni, H., Kalalo, F., \& Majore, C. (2018). Hubungan Kelelahan Kerja dengan Kinerja Perawat di Instalasi Rawat Inap RSU Pancaran Kasih GMIM Manado. e-Journal Keperawatan (e-Kp), Volume 6 Nomor 1, 1-7.

Cahyandi, K., Hendrawan, A., Indriyani, \& Sucahyawati, H. (2018). Stres Kerja dan Kelelahan Kerja Pengaruhnya terhadap Kinerja Guru Sekolah Dasar. Jurnal EMA-Jurnal Ekonomi Manajemen Akuntansi, Volume 3 Nomor 1, 1-13. 
Didjo, M., \& I, W. (2020). Hubungan Kelebihan Waktu Kerja dengan Kelelahan Kerja dan Kinerja pada perawat di ruang Perawatan Intensif RSUD Abdul Wahab Sjahranie Samarinda. Borneo Student Research, Vol 1, Vol 3, $17-15-1724$.

Fitriani, A., L, L., Muhammad, I., \& Rezeki, V. (2020). Analysis of the Effect of Motivation and Training on the Performance of Nurses in Datu Beru Takengon Public Hospital. Journal La Medihealtico, vol. 01, Issue 05, 54-60.

Gurning, F., Luthfi, F., \& Pratama, Y. (2020). Determinan Kelelahan Kerja pada Perawat Pelaksana di Rumah Sakit Teuku Umar Aceh Jaya. Indonesian Trust Health Journal, Volume 3 No. 1, 295298.

Handini, F., Kusnanto, \& Yuswanto, T. (2020). Role of Resilience to Improving The Performance of Health Workers: A Systematic Review. STRADA Jurnal Ilmiah Kesehatan, Vol. 9 No. 2, 551-560.

Hemadewita, Iridiastadi, H., Septiawati, V., \& Yuliani, E. (2020). Psikososial dan Beban Kerja Perawat-Sebuah Penelitian di Salah Satu RS Militer di Indonesia. Jurnal Ergonomi Indonesia (The Indonesian Journal of Ergonomics), Vol. 06 No. 01, 19-30.

Herlina, \& Kondi, A. (2019). FaktorFaktor yang Berhubungan dengan Kelelahan Kerja pada Perawat di Rumah Sakit Awal Bross Bekasi. Jurnal Persada Husada Indonesia, Vol. 6 No. 20, 1-9:
Hidayat, Z. (2016). Pengaruh Stres dan Kelelahan Kerja terhadap Kinerja Guru SMPN 2 Sukudono di Kabupaten Lumajang. Jurnal Penelitian Ilmu Ekonomi Wiga, Vol. 6 No. 1, 36-44.

Karbito, A., \& Oksandi, H. (2020). Faktor-Faktor yang Berhubungan dengan Kelelahan Kerja pada Perawat di RSUD dar. H. BOB Bazar Kalianda Kabupaten Lampung Selatan. Jurnal Ilmu Kesehatan Indonesia (JIKSI) Vol. 1 No. 1, 1-7.

Marthalena, Y., Nuruddin, A., \& Surmiarsih, M. (2020). Hubungan Insentif dengan Kinerja Perawat Berdasarkan Status Kepegawaian di Ruang Rawat Inap RSUD Pringsewu Tahun 2019. Jurnal Signaling STMIK Pringsewu, 4753.

Muller, J. (2020). Workplace Fatigue Statistics and Its Staggering Cost. Ergonomic Trends.

Munandar, S., Permatasari, A., \& Rezal, F. (2017). Faktor yang Berhubungan dengan Kelelahan Kerja pada Karyawan di Matahari Departemen Store Cabang Lippo Plaza Kendari Tahun 2016. Jurnal Ilmiah Mahasiswa Kesehatan Vol. 2/No. 5, 1-11.

Noviyanti, I., \& Supriyadi. (2020). Hubungan Kondisi Kerja dengan Kelelahan Kronis pada Perawat di Ruang Rawat Inap RSUD Wonosari. Jurnal Keperawatan, Vol. 12 No. 2, 71-79. 
Jurnal Penelitian Perawat Profesional, Volume 3 No 2 Hal 319 - 326, Mei 2021 Global Health Science Group 